\title{
SONGS YET TO BE SUNG: WALT WHITMAN AND TAIWAN'S YU KWANG-CHUNG
}

\author{
HSINMEI LIN
}

WHILE THERE ARE CHINESE ${ }^{1}$ POETS who have been influenced by Walt Whitman's work, a strong Whitmanian voice has yet to be properly identified in Taiwan. Yu Kwang-Chung (also written Yu Guangzhong), not only a writer but, like Whitman, a "singer" of his poetry, wrote a tribute poem "To Whitman" in 1954 to celebrate the $135^{\text {th }}$ anniversary of the American poet's birth and to draw attention to his importance in the twentieth century. At the moment that democratic impulses were arriving from the other side of the earth, Yu anticipated the realization of Whitmanian democratic prospects in the Chinese world.

Born in 1928 and raised through his teenage years in China, $\mathrm{Yu}$ fled with his family to Taiwan in 1950 during the Chinese Civil War. $\mathrm{He}$ is a poet both divided and composed by the two lands facing each other across the Taiwan Strait. The dichotomous political courses of the two lands provided $\mathrm{Yu}$ with alternative perspectives for viewing China, Taiwan, and Chinese literature. His importance in Chinese poetry emerged in the early 1950 s, and the political turbulence of his time turned out to provide poetic inspiration and vistas for the majority of his works. Dwelling amid the divergence of culture and history in the Chinese world as well as at the intersection between Chinese tradition and Western modernism, Yu refused to write poetry that merely catered to the political activities and disputes associated with the modernizing movement in Chinese culture. This approach differentiated his works from other contemporary poets in Taiwan who were then passionately engaged in adapting the Western modern styles to Chinese poetry writing.

Having graduated from the Department of Foreign Languages and Literatures at National Taiwan University in 1952, Yu acquired mastery in Mandarin, English, and European languages such as German and Spanish in his early twenties. After a few years of working as a translator of the Ministry of National Defense, an editor for and a co-founder of the Lan-hsing shi-she (Blue Star Poetry Club), and a lecturer in English at National Taiwan Normal University, Yu made 
his name by having his works of translation published in 1957: The Old Man and the Sea by Ernest Hemingway and Lust for Life by Irving Stone. Intrigued by modern art in the West, Yu went to study poetry in the Writers Workshop at the University of Iowa and earned his Master's degree there in 1959. It was then that Yu's poetic journey toward Whitman's modernist revolution was fulfilled and that his poetic aspiration in "To Whitman," written five years before, was realized in America, the home of that poet of democracy, and also the land where Yu advanced his study in modern Western art and sharpened his skills in English poetry writing. In 1964, Yu became a Fulbright Professor, invited by the United States Department of State to embark on a two-year lecturing tour in Illinois, Michigan, Pennsylvania, and New York. ${ }^{3}$ The U.S. Department of Education also in 1969 appointed him the counselor of Foreign Study in the Colorado Department of Education and a visiting professor in Temple Buell College in Denver for another two years. Yu's substantial and global accomplishments in the realm of literature speak for his significance and indicate his contribution to both the Eastern and Western cultures, where his voice as an international poet and a Chinese national has been heard throughout different phases of his life.

Having immersed himself in both English and Chinese poetry, $\mathrm{Yu}$ refused to simply adopt the Westernized styles that were introduced to modern poetry in Taiwan. While Western modern poetry enabled new visions, he argued that the tradition of Chinese poetry had to be combined with it in order to produce quality works. Yu thus aimed for a "Chinese modernism" that would combine the stylistic gracefulness and reserved ethos of traditional Chinese poetry with the formal freedom and the emotional profusion of Romantic and modern Western poetry.

The tribute poem "To Whitman" is an example of this early stage of Yu's poetic style, when he attempted to combine Chinese and Western elements. In my translation, I try to show how the poem still preserves the repetition of certain lines at the beginning and the end of a stanza or in the opening lines of different stanzas. According to the concept of traditional Chinese poetry, this produces a reserved rhythm that adds an elegant touch to the poetico-oratorical expression of a modern style. ${ }^{5}$ Western influence on $\mathrm{Yu}$ is visible in the relaxed metrical forms and straightforward flow of affectivity concerning the social reality of the time. ${ }^{6}$

I quote the whole poem because it reveals Yu's poetic techniquerevolutionary in modern Chinese poetry - which absorbs the Whitmanian spirit of freedom in verse. It also celebrates Whitman's unprecedented significance for America and even for the world, and Yu relies on the driving force of Whitman's ideals when he confronts the failure of democracy in China and Taiwan. While the topic of nationalism is a relatively simple and clear-cut aspect of Whitman's poetry, at least to 
the extent that the United States is his nation, it is obscure and paradoxical in the poetry of Yu. Yu believed that twentieth-century Chinese culture and society needed Whitman's "resonant voice" to deliver the hope of democracy and to provide the appropriate patriotic orientation.

Recognized as a poet of the Chinese modern period, Yu also shares sympathies with Whitman's nineteenth century: the disappointment at unfulfilled democratic visions mixed with an optimism for the coming triumph of true democracy. Formally, however, in the early stages of his writing, from 1949 to 1956, Yu was particularly inclined to write poems that encompassed both the Western style of freedom and the tonal pattern of traditional Chinese poetry, as demonstrated in this tribute poem.

"To Whitman" (trans. by Hsinmei Lin)

-Walt Whitman, on the 135th anniversary of his birth

Whitman, you poet of democracy,

The 20th century needs your strong voice!

The dark age of democracy, the 20th century,

As the dim light of the Statue of Liberty

No longer shines upon half the earth,

Or the agonizing faces of the suffering.

Whitman, you poet of democracy,

The 20th century needs your resonant voice!

You awoke first from the ancient dream,

Like Hercules, your arms struggled,

Struggling, struggling, to be free from the old poetry;

When the weighty iron shackles fell to ground,

So was modern poetry born as a strong infant.

You awoke first from the ancient dream,

You, standing on the astronomical observatory of modern poetry,

Discovered the entire galaxy-humanity,

Discovered the galaxy as the axis turning the universe,

Like Copernicus and Galileo

Discovering the sun as the center of the solar system,

Discovering the earth revolving around the sun.

You in the wilderness of modern poetry,

Discovered man, man and himself.

Then you sang loudly of yourself

Singing of individuals self-esteemed and set free.

Songs for others overwhelm the 20 th century,

How precious and powerful your voice is! 
You first warned man, the head of creatures,

You kept asking us, "Where is the soul?"

For animals do not kneel to their kind,

But a man kneels to another man, or asks another to kneel to him?

For animals do not simper in daytime?

For animals do not weep shamefully in nighttime?

Whitman, you poet of democracy!

Copernicus in poetry, Lincoln in poetry!

The 20th century needs your bold voice!

Tyrants fear your prophetic warnings,

Like ghosts near the end of darkness,

Fearing the sounds of roosters.

Roar, Whitman! You singer of man!

Roar away the 20th-century nightmare!

Infuse the 20th century with your roars,

Like the west wind sweeping away the dying autumn leaves!

Whitman, you poet of democracy!

The 20th century needs your resonant voice!

Your breath is the surging sea.

Like Wordsworth calling for Milton's return,

I stand on the shore of the 20 th century calling for you:

Return, Whitman! Return to the 20 th century!

Immediately at the beginning of the first stanza, $\mathrm{Yu}$ starts with an exclamation as he calls for Whitman, the "poet of democracy." This oratorical flourish suggests that the poem be "spoken," not just "read," a style that recalls the bardic characteristics of Whitman's own poetry, which uses a large number of exclamatory statements to "contain [its] multitudes." When Yu confesses his reasons for "summoning" this nineteenth-century poet into the twentieth century, "the dark age of democracy," he draws Whitman's vigorous poetic force into the poem, and it is understandable that Yu would find 1954 to be a dark age for democracy. ${ }^{8} \mathrm{He}$ looked back at his participation in Chinese history until then and was depressed by the political conditions he had been compelled to reside within. He then recalled the energy and passion in Whitman's democratic songs and recognized the soothing voice as potentially capable of curing the politico-democratic stagnation in his own time.

$\mathrm{Yu}$, as a teenager who had undergone the turmoil during and after the Chinese Civil war in both China and Taiwan, felt the anguish of the people on these two lands as he saw "upon half the earth," the East, "the agonizing faces of the suffering." For Yu, a representative sufferer 
and an observer from both the mainland and the island, the twentiethcentury East had been "dark" and despairing. He repeats the word "democracy" three times in the first stanza, seemingly to register his despair at seeing no sign of democratic realization in twentieth-century China. With the promise of Whitman's twentieth-century world unfulfilled, Yu proposes that the American poet sing again to brighten his oriental sky, just as once Whitman had called out for the Chinese world: "You Chinaman and Chinawoman" (PP 295). Yu longs to "hear" the "resonant voice" of Whitman's lyrics, to release his people and the lands from the shackles of their past, and to cruise along with Whitman on his ferry as Whitman promises-"distance avails not, and place avails not" and "the dark" shall never fall "upon you alone" (310-311).

Yu's admiration for Whitman's songs propelled him to actually "Whitmanize" his own poetic creation, especially in the way he writes his ideals of democracy into his own poetry. The key is that while Whitman sings songs to celebrate himself, he does not sing only for himself. For Whitman, an individual is an embodiment of every single human being as America itself is "the race of races"- a conglomerate of individuals of diverse backgrounds grouped together to form a whole. Hence, the idea of singing oneself is identical, at least potentially, to singing all other men and women (PP 7). According to Whitman, in order to sing for others, one needs to first sing for himself, the self being the cornerstone on which the ability to sing for others is built. This perspective on the self-other relationship is discussed in Yu's poem when he declares critically that the "songs" in the twentieth century are all sung "for others." Yu's concern is that the self is to be associated with the subject of his poetry: mankind. This is indeed a cogent indication of how Whitman's songs of the self began to be sung in the East, in the modern period of Taiwan, through the "songs" of Yu.

In the later part of this poem, Yu switches the focus from Whitman's poetic themes to the form and style of his poetry. In addition to seeing Whitman as "the poet of democracy," he further addresses him as the "prophet," "rooster," and the "singer of man." Yu modifies the words commonly utilized to discuss poetry such as "lines" or "writer" and instead emphasizes the feature of vocality and musicality in Whitman's poetry, making apparent another influence Whitman has had on Yu's poetry. Yu makes great effort to perform the "sounds" in his poetry. In a poem titled "Music Percussive," Yu lends his passion for rock-and-roll music to his poetic creation. He places emphasis on the rhythm and intonation throughout the poem, a technique that demonstrates his meticulousness about how sounds can affect the rhythm of poetry regardless of the use of a rhyme scheme. ${ }^{9}$ 
While Whitman sang the songs of himself to and with the public in nineteenth-century America, Yu is known for writing on the premise that his poems are "singable" in twentieth-century Taiwan. The power of oratory thus defines both of the poets. Yu reads Whitman's poetry as the "West wind" and his "breath" as the "surging sea" in order to vocalize Whitman's literary power, as if it has the ability to change and revive seasons and to carve the shape of the earth. Yu believes a poet should be capable of promoting his own artworks, and performing the poetry encourages that promotion. To Yu, Whitman's art of oratory stands highest among all the "performances."

Yu and Whitman, as poets of the modern periods of the East and West, share a common belief in the power of poetry, revolutionary poetic forms and techniques, and intense patriotic sentiments. Both are distinguished from their contemporaries by these innovative and exuberant tendencies to genuinely connect their poetry to the times in which they are situated.

They are both atypical modern poets, in that they do not intend to completely dismiss the literary values of the Old World while they work to promulgate the poetic style and voice they have developed for the modern period. Yu and Whitman are the "Romantic Realists" in the modern periods of the East and the West.

\section{University of Washington}

\section{NOTES}

1 In this essay, the word "Chinese" pertains not only to Mainland China but to the Chinese-language-speaking culture as a whole.

$2 \mathrm{Yu}$ frequently recites his poems on literary occasions such as poetry recitation projects and speeches that he has been invited to in both Eastern and Western corners of the world. He thinks a good poet needs to "perform his poetry" (Professor Kao, Yi-han, "A Talk with Yu, Kwang-chung on Poetry: Joy over the Sailor's Return" [literature.idv.tw/bbs/simple/index.php?t5232.html].)

3 Yu gave lectures on East Asian studies at Bradley University and Central Michigan University, and on Chinese poetry and the Chinese history of literature at Gettysburg College and at New York State University colleges at Buffalo, Potsdam, Cortland, and Brockport. He was invited to give speeches at Goucher College in Baltimore and Dickinson College in Carlisle during his stay in Gettysburg (Fu, Mong-li, The Child of Cornel [Taipei: Commonwealth, 1999]).

4 Jia-qi Xie, "Study on Cultural Identity in Yu Kwang-chung's Poetry." National Chungcheng University, National Digital Library of Theses and Dissertations in Taiwan, 2003.

5 Yu said that he was trained with the traditional rules and forms first and then tried to escape from the restrictions in order to produce "rules" of his own in poetry writing. 
6 Freedom in verse was pursued as Chinese poetry stepped into its modern period in the early 1950s. Emotional expression materialized as poetic language was "modernized" with the emphasized quality of oratory in Yu's poem. Yu demonstrates his idea of making Chinese voices known, as he speaks for them, to the forerunner of democracy, the West. For reference, see Michelle Yeh and David Malmqvist, Frontier Taiwan: An Anthology of Modern Chinese Poetry (New York: Columbia University Press, 2001).

7 Walt Whitman, Poetry and Prose, ed. Justin Kaplan (New York: Library of America, 1996), 27-88; hereafter, $P P$.

8 In a speech at National Chengchi University in Taiwan on May 24, 2010, Yu made it explicit that the "dark age" in the poem refers to the threat of the Communist Party of China.

9 When Yu was invited to a poetry recitation project in Monterey Park in Los Angeles in 2006, he gave a speech about the inseparability of music and poetry. A poet can be thought of as the composer of the poems, as a reciter is to be viewed as the performer of the poems. Yu, being the composer and the performer of his poetry, has mastered these two essential elements in his poetic achievement. 